\title{
In vitro cytotoxicity analysis of sulfated polysaccharides from green seaweed Codium tomentosum Stackhouse, 1797
}

\author{
Pagolu Navya, Samantha Sekar Khora* \\ Department of Integrated Biology, School of bioscience and technology, VIT University, Vellore-632014, Tamilnadu, India.
}

\begin{tabular}{l} 
ARTICLE INFO \\
\hline Article history: \\
Received on: 13/02/2017 \\
Accepted on: 09/04/2017 \\
Available online: 30/06/2017 \\
\hline Key words: \\
Codium tomentosum, \\
Polysaccharides, Toxicity, \\
L929 cells, MTT assay.
\end{tabular}

\begin{abstract}
Algae polysaccharides are commonly used in alternative medicine. Toxicity study of the isolated polysaccharide was carried out prior to the exploration of its bioactivities. In the present study we examined the toxicity of sulfated polysaccharides isolated from marine green algae Codium tomentosum. In this in vitro study, normal mouse fibroblast cells (L929) cells were used and Cytotoxicity was screened using 3-(4, 5-d imethylthiazol-2yl)-2, 5 diphenyltetrazolium bromide (MTT) reduction assay. This study showed that Polysaccharides from Codium tomentosum had no toxic effects, so these polysaccharides can be utilized for future studies.
\end{abstract}

\section{INTRODUCTION}

Marine natural products are well known for their facile applications to therapeutics and today research has been focused on finding pharmaceutical agents with selective pharmaceutical effects and less toxicity. Natural products have been the source of medicinal use since the advent of traditional medicine and healing, and remain a dominant source till date. The key factor that should be examined for the development of biomolecules as drugs for various diseases is their toxicity in mammalian cells (Lahlou, 2013). Anticipated increase in therapeutic use of polysaccharide and their role in new therapeutic formulations need the creation of complete toxicological data to find out its safety. In drug development the passage from discovery to preclinical study is a continuous process and results of pharmacology and toxicology testing often important in medication. Although various bioactivities of the sulfated

* Corresponding Author

Email: sskhora@vit.ac.in polysaccharides are available, little information on their toxicity is presently available. The polysaccharides from several sources exhibit no toxic effect even at high concentration (Gideon and Rengasamy, 2008).

Cell culture is highly desirable, as it is an impotent tool to study problems of clinical relevance, mainly those associated with diseases and studies of cell toxic machineries. Cytotoxicity testing is important for determining the potential toxicity of the compounds being studied. Now a day, the calorimetric MTT assay system has been used for determining the cell viability in vitro. In this assay living cells changes the MTT into purple-colored MTT formazan and in dead cells decrease the cellular MTT reduction is a sign (Abe and Matsuki, 2000). Mostly, cytotoxicity screening of algal polysaccharides were done in cancerous cells and very rare in normal cell cultures. Cytotoxicity studies of polysaccharides from marine algae with normal cell lines have not been studied extensively and this is essential for the safety evaluation. So this study was under taken to evaluate the potential cytotoxicity of polysaccharides isolated from marine green seaweed codium tomentosum in normal mouse fibroblast cells (L929). 


\section{MATERIALS AND METHODS}

\section{Collection of Seaweed and Processing}

The fresh specimens of green seaweed Codium tomentosum stockhouse, 1797 were collected from Tamil Nadu coast, India, in August, 2015. The seaweed species was identified by J.R Ramalingam, Regional Centre of Central Marine Fisheries Research Institute (CMFRI), Mandapam, Tamilnadu, India. The collected seaweed was first rinsed in seawater and then in distilled water for removing the macroscopic epiphytes and extraneous matters. The specimen was dried and powdered.

\section{Ultrasound-enhanced Extraction of Polysaccharides (UEP)}

Ultrasound-enhanced extraction of polysaccharides was done by following the method as described by Shao et al., 2013 with little modifications. $100 \mathrm{~g}$ of codium tomentosum powder was assorted with distilled water at a $\mathrm{m} / \mathrm{v}$ ratio of 1:10 and kept at room temperature for overnight. The Sonics vibra cell (VCX500), input ultra-sound power was $500 \mathrm{~W}, 20 \mathrm{KHz}$ was used. The extraction time and tempersture was $30 \mathrm{~min}$ and $45^{\circ} \mathrm{c}$ respectively. After cooling the slurry was filtered and evaporated to $1 / 4$ th of the original volume then precipitated with ethanol. The precipitate obtained was collected by centrifugation and lyophilized.

\section{Partial Purification of Sulfated Polysaccharides}

The UEP were further purified by column chromatography. The crude polysaccharides were mixed with distilled water $(10 \mu \mathrm{g} / 10 \mathrm{ml})$ centrifuged at $6000 \mathrm{rpm}$ for $10 \mathrm{~min}$ and the supernatant was collected and poured in a DEAE-cellulose column $(3 \times 45 \mathrm{~cm})$ equilibrated with distilled water. The column was washed out step by step using distilled water having a linear gradient of $0-3 \mathrm{~mol} / \mathrm{NaCl}$ at a flow rate of $0.55 \mathrm{ml} / \mathrm{min}$ and 15 fractions were collected. They were further proceded for the carbohydrate content. The fractions which contains high amount of carbohydrates were mixed together and dialyzed for 24 hours by using distilled water. The active fractions were identified by carbohydrate estimation using phenol-sulphuric acid method and it was used for the further study.

\section{Analysis of biochemical composition \\ (i) Estimation of total carbohydrates}

Phenol sulphuric acid method was used for determining the total carbohydrate content as followed by Dubois et al. (1956). $100 \mathrm{mg}$ of polysaccharides was dissolved in $5 \mathrm{ml}$ of $0.5 \mathrm{~N} \mathrm{HCl}$ and kept in boiling water bath for 3 hours. The solution was then neutralized with sodium carbonate and the volume was made up to $100 \mathrm{ml}$ with distilled water. 0.1 and $0.2 \mathrm{ml}$ of the solution were used for the estimation of total carbohydrates. D-glucose (Stock: 1mg / $\mathrm{ml}$ ) was used as the standard.

Various concentrations of standard and test solutions were taken in different test tubes and by using distilled water the volume was made up to $1 \mathrm{ml} .5 \%$ phenol of $1 \mathrm{ml}$ was taken and added to all the tubes followed by $5 \mathrm{ml}$ of $96 \%$ sulphuric acid. The mixtures were shaken well and incubated for 10 minutes in room temperature. After incubation, tubes were kept in a water bath at $30^{\circ} \mathrm{C}$ for 20 minutes and the absorbance was taken at $490 \mathrm{~nm}$.

\section{(ii) Determination of sulfate content}

The amount of sulfate presented in polysaccharides was estimated by using barium chloride gelatin method as proposed by Lloyd et al. (1961). Crude polysaccharide sample of about $0.1 \mathrm{ml}$ $(\mathrm{mg} / \mathrm{ml})$ was used for the estimation of sulfate concentration. Potassium sulfate $(0.6 \mathrm{mg} / \mathrm{ml})$ at various concentrations was used as the standard.

They were taken in different test tubes and were recompense with $0.2 \mathrm{ml}$ solution with hydrochloric acid. Then 3.8 $\mathrm{ml}$ of trichloroacetic acid was added and followed by $1.0 \mathrm{ml}$ of barium chloride gelatin solution and kept at room temperature for $15 \mathrm{~min}$ of incubation, then absorbance were read at $360 \mathrm{~nm} .0 .2 \mathrm{ml}$ hydrochloric acid solution was taken as a blank and the amount of sulfate was calculated from the standard graph.

\section{(iii) Determination of uronic acid content}

Estimation of uronic acid content by the carbazolesulfuric acid method as described previously by Egan et al.1981. Polysaccharide samples, standards and controls $(250 \mu \mathrm{l})$ were cooled in an ice bath. Ice cold reagent A $[0.95 \mathrm{~g}$ of sodium tetraborate decahydrate was dissolved in $2 \mathrm{~mL}$ of hot water and 98 $\mathrm{mL}$ of ice-cold concentrated sulphuric acid was added $(1.5 \mathrm{ml})]$ was added with mixing and cooling in ice bath and then was heated at $100{ }^{\circ} \mathrm{C}$ for $10 \mathrm{~min}$. After it become cooled, $50 \mu \mathrm{l}$ of the reagent $\mathrm{B}$ [125 $\mathrm{mg}$ of carbazole was dissolved in $100 \mathrm{~mL}$ of absolute ethanol] was added and mixed well. Reheated at $100{ }^{\circ} \mathrm{C}$ for $5 \mathrm{~min}$. Cooled rapidly to room temperature and absorbance was read at $525 \mathrm{~nm}$. The glucuronolactone was taken as a standard

\section{Cytotoxicity assay \\ Cell culture}

L929 cells (mouse fibroblasts) were purchased from National center for cell science (NCCS), Pune. L929 cells were mostly used for cytotoxicity test, because it is easy to store, culture and subculture in vitro, and it was used as cell lines of cytotoxicity screening for most of the compounds (Richardson et al., 1993). The cells $2-4$ X $10^{5}$ were seeded in 96 well cell culture plate with DMEM medium (Himedia) supplemented with $1 \%$ antimycotic antibiotic (Himedia) and 10\% FBS (Himedia), then incubated for $24 \mathrm{hr}$ in $\mathrm{CO} 2$ incubator at $37{ }^{\circ} \mathrm{C}$.

\section{Preparation of test solutions}

Dissolved MTT in Dulbecco's Phosphate Buffered Saline, $\mathrm{pH}=7.3$ (DPBS) to $5.1 \mathrm{mg} / \mathrm{ml}$. Filtrate and sterilize the MTT solution by using a $0.2 \mu \mathrm{M}$ filter into a sterile, dark container. Soluble solution was made in a vessel which is impervious to solvent and kept in an aerated fume hood. Prepared $40 \%$ (vol/vol) dimethylformamide (DMF) in $2 \%$ (vol/vol) glacial acetic acid, then Added 16\% (wt/vol) sodium dodecyl sulfate (SDS) and dissolve. 


\section{Determination of cell viability by MTT assay}

Prepared cells (L929) and test samples in 96-well plates with a final volume of $100 \mu \mathrm{l} /$ well. Incubate for certain time and added $10 \mu \mathrm{l}$ MTT Solution per well to have a last concentration of $0.45 \mathrm{mg} / \mathrm{ml}$. Incubate 1 to 4 hours at $37{ }^{\circ} \mathrm{C}$. Add $100 \mu \mathrm{l}$ soluble solutions to all wells for dissolving formazan crystals. Read the absorbance at $570 \mathrm{~nm}$ and percentage of cell viability is calculated by using following formula: Percentage of viability $=($ Test OD/Average control OD) X 100.

\section{RESULTS AND DISCUSSION}

\section{Yield of the crude extract}

Extraction of bio-compounds is usually performed by conventional methods. It involves consumption of more amounts of solvent and an increase in the extraction time (Yan et al., 1999). The Ultrasound Extraction(UE) method provides important advantages for the extraction process of organic compounds; it can minimize the extraction time and solvent usage (Mason et al., 1996). Currently, to extract active compounds such as rutin and querceting sonication have been utilized (Yang et al., 2008), antioxidants (Albu et al., 2004). However, there are fewer evidences on ultrasound-enhanced extraction of sulfated polysaccharides from seaweeds (Shao et al., 2013)

Sulfated Polysaccharide were extracted using ultra sonication and the dry weight of the crude polysaccharides were extracted from $100 \mathrm{~g}$ of the seaweeds (Codium tomentosum) powder were found to be $16.2 \mathrm{~g}$. The crude polysaccharides were partially purified in DEAE cellulose52 using $1 \mathrm{M}$ sodium chloride and the yield was $12.5 \mathrm{~g}$. The active fractions were identified by carbohydrate estimation using phenol sulphuric acid method and it was used for the further study. The chemical structure and composition of polysaccharide is important to understand their activities. Composition of polysaccharide was analyzed and was found to constitute carbohydrates, sulphate and uronic acid.

The percentage of total carbohydrate, sulfate and uronic acid content was found to be $65.84 \pm 0.27 \%, 16.38 \pm 0.81 \%, 8.31$ $\pm 0.18 \%$ respectively. Secondary metabolites show medicinal properties at the same time they assume to be toxic under different stressed conditions. Therefore, toxicity testing is of therapeutic screening and it can be exhibit some of the risks that may correlate with their uses. This in turn will make easier in the recognition of toxicants at a starting stage of drug discovery.

The cytotoxic effect of the polysaccharides from Codium tomentosum was investigated using MTT assy and results are shown in Table 1. From the study, it was observed that the cytotoxicity of the polysaccharides from Codium tomentosum were found to be dose dependent and did not shows any lethality to the healthy normal cell lines L929. However, the cells started proliferation markedly with increased concentration (figure 2). Although this proliferation activity indicates that the isolated polysaccharides may have a role to play in the process of wound healing. The wound healing process involves a series of cellular events like cell migration, proliferation, and remodeling. Upon the onset of the inflammatory response, fibroblasts begin to proliferate and migrate into the wound area. Collagen and fibronectin are subsequently deposited in the wound bed, serving as a temporary matrix on which epithelial cells can migrate (Singer et al., 1999).

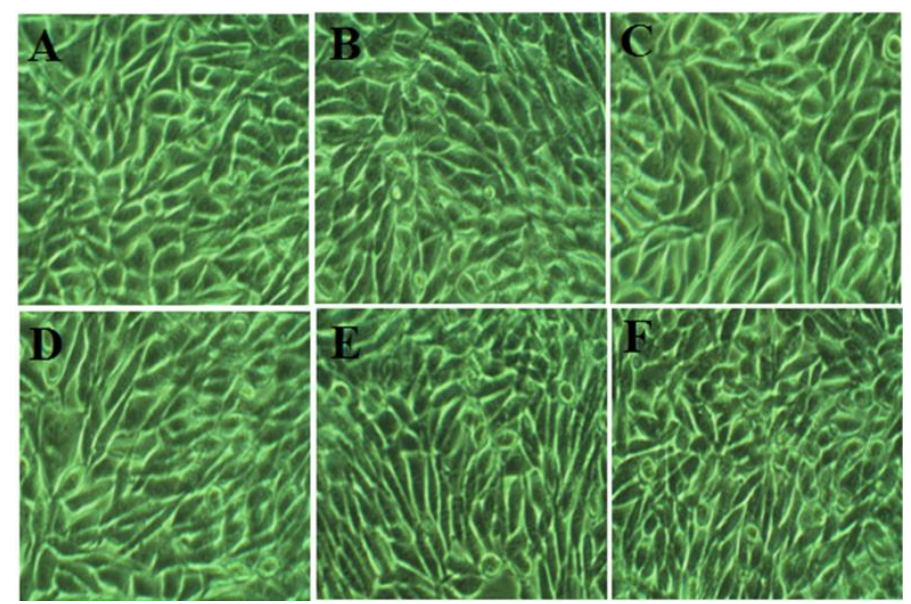

Fig. 1: Effect of isolated polysaccharides on L929 cell at different concentrations (A: Control; B: $100 \mu \mathrm{g} / \mathrm{ml}$; C:250 $\mu \mathrm{g} / \mathrm{ml}$; D: $500 \mu \mathrm{g} / \mathrm{ml}$; E: 750 $\mu \mathrm{g} / \mathrm{ml} ; \mathrm{F}: 1000 \mu \mathrm{g} / \mathrm{ml})$

Table 1: Effect of isolated polysaccharides on L929 cell lines (Values are average of triplicates)

\begin{tabular}{ccc}
\hline Tested concentration $(\boldsymbol{\mu g} / \mathbf{m l})$ & OD at $\mathbf{5 7 0 n m}$ & \% of cell viability \\
\hline 100 & $0.510 \pm 67$ & $147.09 \pm 67$ \\
250 & $0.688 \pm 33$ & $199.46 \pm 67$ \\
500 & $0.724 \pm 06$ & $209.86 \pm 67$ \\
750 & $0.735 \pm 10$ & $213.00 \pm 10$ \\
1000 & $0.742 \pm 33$ & $215.01 \pm 10$ \\
Control & $0.345 \pm 33$ & 100 \\
\hline
\end{tabular}

\section{CONCLUSION}

The polysaccharides from green algae codium tomentosum shows no toxicity against mouse fibroblast cells instead it shows proliferating activity. Proliferation and migration of cells is a series of intricate cellular events involved in wound healing process, so it might have potential therapeutic use in guiding cell movement in wound healing. Hence, further study is needed to explore its bioactivities.

\section{ACKNOWLEDGMENT}

This work was carried out with support of VIT University for providing the facilities to conduct this part of research work.

Conflict of interests: There are no conflicts of interests.

\section{REFERENCES}

Abe K, Matsuki N. Measurement of cellular 3-(4,5dimethylthiazol $-2-y-1)-2,5$ diphenyltetrazolium (MTT). Neuroscience Research, 2000; 38:325-329.

Albu S, Joyce E, Paniwnyk L, Lorimer JP, Mason TJ. Potential for the use of ultrasound in the extraction of antioxidants from Rosmarinus officinalis for the food and pharmaceutical industry. Ultrason. Sonochem, 2004; 11:261-265. 
Barrio GD, Parra F. Evaluation of the antiviral activity of an aqueous extract from Phyllanthus orbicularis. J Ethnopharmacol, 2000; 72:317-322.

Dubois M, Gilles KA, Hamilton JK, Rebers PA, Smith F. Colorimetric method for determination of sugars and related substances. Anal. Chem, 1956; 28:350-356.

Egan H, Kirk RS, Sawyer R. Pearson's Chemical Analyses of Foods. 8th Edition London-UK; 1981.

Kennedy DO, Wightman EL. Herbal extracts and phytochemicals: plant secondary metabolites and the enhancement of human brain function. Adv. nutr, 2011; 2:32-50.

Lloyd AG, Dodgson KS, Price RG, Rose FAI. Polysaccharide sulphates. Biochimica et Biophysica Acta, 1961; 1:108-115.

Mary SD and Gayathri D. In vitro Cytotoxicity and Glucose Uptake Activity of Fruits of Terminalia bellirica in Vero, L-6 and 3T3 cell lines. Journal of Applied Pharmaceutical Science, 2015; 5(12):092-095

Mason TJ, Cordemans ED. Ultrasonic intensification of chemical processing and related operations: a review. Trans. Inst. Chem. Eng, 1996; 974:511-516.

Mouhssen Lahlou. The Success of Natural Products in Drug Discovery Pharmacology \& Pharmacy, 2013; 4:17-31.

Niles AL, Moravec RA, Riss TL. In vitro viability and cytotoxicity testing and same-well multi-parametric combinations for high throughput screening. Curr Chem Genomics, 2009; 3:33-41.

Paul TG and Rengasamy R. Toxicological Evaluation of Fucoidan from Cladosiphon okamuranus. Journal of Medicinal Food, 2008; 11(4):638-642.

Richardson RR, Miller JA, Reichert WM. Polyimides as biomaterials preliminary biocompatibility testing. Biomaterials, 1993; 14:627-635

Samaha HS, Kelloff GJ, Steele V, Rao CV, Reddy BS. Modulation of apoptosis by sulindac, curcumin, phenylethyl-3methylcaffeate and 6-phenylhexyl isothiocyanate: apoptotic index as a biomarker in colon cancer chemoprevention and promotion. Cancer Research, 1997; 57:1301-1305.
Shahneh FZ, Valiyari S, Azadmehr A, Hajiaghaee R, Yaripour S, Bandehagh A, Baradaran B. Inhibition of Growth and Induction of Apoptosis in Fibrosarcoma Cell Lines by Echinophora platyloba DC: In vitro Analysis. Adv Pharmacol Sci, 2013; 5:129-31.

Shao P, Xiaoxiao C, Peilong S. antioxidant and antitumor activities of different sulfated polysaccharides isolated from three algae. International Journal of Biological Macromolecules, 2013; 62:155-161.

Shao P, Xiaoxiao C, Peilong S. In vitro antioxidant and antitumor activities of different sulfated polysaccharides isolated from three algae. International Journal of Biological Macromolecules, 2013; 62:155-161

Singer AJ, Clark RAF. Mechanisms of disease: Cutaneous wound healing New Eng. J Med, 1999; 341-738.

Vinatoru M, Toma M, Radu O, Filip PI, Lazurca D, Mason TJ. The use of ultrasound for the extraction of bioactive principles from plant materials. Ultrason. Sonochem, 1997; 4:135-139.

Yan X, Suzuki M., Ohnishi-Kameyama M, Sada Y, Nakanishi T, Nagata T. Extraction and identification of antioxidants in the roots of yacon (Smallanthus sonchifolius). J. Agric. Food Chem, 1999; 47:47114713.

Yang Y, Zhang F. Ultrasound-assisted extraction of rutin and quercetin from Euonymus alatus (Thunb.) Sieb. Ultrason. Sonochem, 2008; 15:308-313.

\section{How to cite this article:}

Navya P, Khora SS. In vitro cytotoxicity analysis of sulfated polysaccharides from green seaweed Codium tomentosum Stackhouse, 1797. J App Pharm Sci, 2017; 7 (06): 033-036. 